\title{
The Role of Church and Parent in Early Childhood Education in the Central Highlands of Papua
}

\author{
Imron Arifin \\ Educational Administration Department \\ Universitas Negeri Malang \\ Malang, Indonesia \\ imron.arifin.fip@um.ac.id
}

\author{
Agustinus Hermino \\ Universitas Negeri Malang \\ Malang, Indonesia \\ agustinus_hermino@yahoo.com
}

\begin{abstract}
The research aims to provide an overview of the role of the church in the central highlands of Papua in giving attention to early childhood education for children to attend school. This research also intends to give understanding to parents about parenting and the community in providing proper education to children at the early age. The result revealed that parents assume that the children who attended school in the early childhood education will reduce their time working in the field and many childhood education teachers come from the other ethnic communities, then the use of Indonesian language would be difficult for children to understand because at home parents used the language of the local tribe. Second, the general community in Papua is abiding society on religion and respect for church leaders. Their role is not only in church services but also sensitise the public about the importance of education and parenting.
\end{abstract}

Keywords-early childhood education, role, church, parenting

\section{INTRODUCTION}

Blessed with abundant natural resources and fertile soil, the Papua's Central Mountains has an important role in determining the success of development in Papua province in particular and Indonesia in general. As migrants from other parts of the country have flocked to the Central Mountains, the ratio between the natives is now well-balanced. Ironically, the migrants have dominated the business and economy sectors as well as job opportunities, while the native Papuans become marginalized and lost their customary lands acquired by companies who wish to expand their agribusinesses. The native Papuans now become farm workers on their ancestral land that belonged to them for thousand years.

Jayawijaya District consists of 40 districts, 328 villages and 4 sub-districts with a total area of $13.925,31 \mathrm{~km}^{2}$. According to the Jayawijaya Statistics Agency (BPS) [1], the total population in Jayawijaya regency in the mid-2013 stood at 203.085 people with 99,512 females and 103.573 males. Jayawijaya regency was developed based on UU No. 12 1969 with its capital Wamena. Jayawijaya regency borders with regencies of Lanny Jaya, Tolikara, Central Mamberamo in the west; Yahukimo and Yalimo in the East; Nduga and Yahukimo in the South; and Central Mamberamo and Yalimo in the North.

The Central Highlands Papua education system only began in the 1950 s by private and group missionaries supported by various churches. This missionary studies, tribal languages and translates the Bible into these languages. Literacy is a tool to spread the gospel and missionaries take it seriously. Missionaries laid the foundations of the educational tradition in areas such as the Pyramids and Ninia to date. They established schools in Wamena and Sentani, which are currently one of the best schools in Papua.

Until 1962, the Dutch as rulers of the Papua region recognized the inability of their government to provide education to residents in the Central Mountains so they assigned the church to do so, then they channelled funds through the church to pay the salaries of teachers assigned by the church. Instructions at school use Dutch after 1962 new Indonesian language is taught. To ensure education standards, the Evangelical Church Education and Schooling Foundation (YPPGI) was established in Papua [2].

In 1980, the Indonesian Government began to take over the education system after the Dutch left Papua. The control of the health care system of the missionaries was held by the government so the church felt that they could concentrate more on their initial assignments, preach the gospel and worship when the church gave up their social roles, their authority also declined in the land of Papua. The teacher becomes a government employee and the school adopts a learning system conducted by the Dutch into a national curriculum. In fact, the government has never really taken over, there is no systematic mechanism and comprehensive cooperation with foundations that manage most schools in Papua [2].

With regard to early childhood education in the central highlands of Papua, the research conducted by the World Vision Indonesia [3] mentioned that one weakness of basic education in the middle mountain range Papua is due to a very small number of early childhood education provided and the low awareness of parents in the education of children in the family.

The existence of the church's role in the development of early childhood education in the mountains of central Papua as well as set out in documents the foundation of Christian Wamena [3] were found to support local authorities in improving the quality of education in the central highlands of Papua, the involvement of the church not only in the church service alone but the church also plays an active role and evident through the establishment of early childhood education as the basis of education in the family.

In addition to the facilities and human resources issues, another major cause is the lack of stimulation provided in early childhood. In Papua, more children grow and develop naturally without being given a good education. The lack of a 
system of teaching from an early age, as early childhood or kindergarten, would make education in Papua became late and unstructured. In addition, customs and local culture also indirectly become an obstacle to the education system in Papua.

\section{METHOD}

This research is a qualitative approach, which has two focus, such as (1) the role of parents in children's education; and (2) the role of the church in the growth of early childhood education. The research was conducted for 14 months in the central highlands of Papua, interacting with the public, in general, to observe and interview for completion of this study.

Location of the study in four schools of early childhood education which is in the district of Wamena in Papua Jayawijaya. The four schools of early childhood education are: (1) ECE Wesaput; (2) ECE Christian Foundation Wamena; (3) ECE Advent; and (4) ECE Santa Theresia, all are managed by each church in Wamena. Some informants in this research were: (1) school principal of early childhood education; (2) tutors or teachers; (3) parents; (4) several staffs at the local education department; and (5) several staffs at the local family welfare program.

To get in-depth research results, data collection is done through interviews, observation, and documentation studies. Researchers as key instruments interact and direct observation during the learning process at PAUD institutions, and when children are at home/family. This research was conducted for 14 months with continuous observation. Interviews were conducted with parents, religious leaders, community leaders around the school, school principals, and teachers who taught in the PAUD, and leaders and staff of the education office. The place of the interview was done in their homes, when there were village meetings, at school, in the church, and at the education office.

Data analysis was performed using a flow analysis technique including models: Data collection, data reduction, data display, and conception drawing or verifying. Data analysis was carried out at each site and across sites when all data were collected by a modified analytical inductive model. The findings on the first site were then induced in the second, third, and fourth sites by cross-site analysis as the final findings. Checking the validity of data is done through the degree of credibility among other persistent observations, triangulation of resources, triangulation of techniques, triangulation of time, member check, and referential adequacy check. Checks are also carried through dependability and confirmability.

\section{RESULT AND DISCUSSION}

\section{A. The Role of Parents in Children's Education}

Problems of the low role of parents in providing educational support to children as set out in World Vision Indonesia [3] that parents still think children need not attend primary school through early childhood education, but if old enough, and children are going to school, then children put into primary school.

With regard to the conditions of parental support in early childhood education, then some of the research findings such as (1) lack of parental education of children has resulted in low awareness of parents in children's education; (2) the child is an asset to help parents work in the garden; (3) parents to have many children so it is unthinkable for a child's education; (4) issue of economy parents that work in the garden is more important than thinking about the child's school; and (5) the influence of the mother tongue, which is where the language of instruction in schools is Indonesian parental home while using the mother tongue as parents unfamiliar with Indonesian.

First, with regard to lack of education of parents of children that resulted in a low awareness of parents in the education of children, it is because most of these parents have the background dropped out of school when elementary school, or secondary schools. Unlike the parent is able to finish up high school, the child support will be much better than the dropout current junior high school or elementary school. The condition as stated by Grant [4] that the circumstances consideration parental education affects parents in mentoring or motivating children to attend school. As well as Higgins, et al [5] also suggests that early childhood education is an important education for children entering school age, and to this, the mentoring of parents is very important that children feel motivated to start to enjoy learning.

Secondly, with regard to the child's parents is an asset to help work in the garden. It is a tradition in the central highlands of Papua in general that in order to expedite the work of parents in the garden, the better use of child labour. However, when it comes to early childhood or the presence of school-age children in the garden with his parents is in order to become accustomed to working life or the life of the natural joint. This condition also stated in MoEC [6] that children in remote areas generally do not receive early childhood education because more was asked to accompany her parents to live in the garden. Knowles, et al [7] argued that the need for education for parents in order to raise awareness of the importance of education for children in the family. Similar with the previous statement, Myers [8] also mentioned that awareness of the importance of education or awareness of the importance of education for parents is a social dynamic that should get the attention together so that children in the age range that has been in time can enjoy a school education should be obtained as well.

Third, with regard to the parents to have many children so it is unthinkable for a child's education. It's like most of the tradition in the central highlands of Papua that many children make a lot of luck. This condition is due to the status of children in the future will be able to be the heir or the keeper of the garden or natural resources owned by the parent. The condition as stated by Grant [4] that people need to make them aware of the importance of the position of the child in improving the quality of life in the family as well as the efforts of parents to give good education to children. The notion that many children is a lot of luck but is not 
supported by a good level of education, it would bring economic problems worse condition.

Fourth, with regard to the problem economy parents that work in the garden is more important than thinking about school children. It's like in the majority of families who live in the central highlands of Papua, that poverty occurs due to low parental education. Given the poverty, the presence of children in the family will be important for the family and parents because the child will be working with parents in managing their gardens to make money for their survival. With regard to this condition, Saleem \& Imam [9] economic factors suggest that sometimes parents make children in unfavourable conditions because parents will be thinking about how to survive with the work of the thinking about the child's school. Similarly, Hermino [10] also mentioned that in early childhood, then in time the child can go to school, but because of the economic condition of parents, the child will be a friend to help parents in their work.

Fifth, with regard to the influence of the mother tongue, which is where the language of instruction in schools is using Indonesian, while at home parents uses the mother tongue in everyday conversation since they are unfamiliar with Indonesian. To this condition in the central highlands of Papua with many tribes, each tribe has its own language, and thus the unifying language in schools is the national language is Indonesian. But due to the poor parental understanding of the importance of education for children, especially in early childhood, hence the use of the mother tongue is the main language at home and very few parents who use Indonesian. This resulted in children not fully understand taught by teachers at the school since the children entered into early childhood education. Against this case, as stated by Grant [4] that the need for the public to use the national language as the language of daily life and in the family, to help children understand the language of instruction by the teacher while in school. Arifin [11] also stated that using the language appropriate influence children understanding in learning for early childhood education level.

Referring to all the explanations above, it is very important to involve parental care in Early Childhood Education (ECE), because parents play a very important role in the development of these children. Parents' involvement will create the comfort of attention and affection for children during their growth and development. Research found the role of parents in children in the Central Highlands region of Papua, especially in Jayawijaya Regency: (1) forming parent organizations or groups in each ECE; (2) establish a consultation service centre for parents if there are problems consulted; (3) involving parents in certain activities in ECE; (4) involving parents in planning and organizing ECE activities; and (5) promoting visiting teachers to parents' homes to build good relations between parents and teachers.

Based on the above conditions, it can be interpreted that parents play a very important role in the development of their children. Most children spend their time at home with parents or caregivers. Therefore, it is very important to involve them. By involving parents, education and coordination of relationships between schools and parents can be well established. Some observations show that many parents provide education and stimulation to their children to teachers, and some do not understand how good children's education is at home [9].

\section{B. The Role of the Church in the Growth of Early Childhood Education}

Churches in Papua in general and especially in the central mountains has a role not only in worship alone but, more broadly, are involved in the public awareness of the importance of education for children. This condition is similar to research finding revealed by Elisabeth [12] and Nugroho [13].

With regard to early childhood education, then there are three things the church's role: (1) as the centre of awareness for parents; (2) as government partners to provide skills training to teach the teachers; and (3) as a partner of the government in providing learning facilities in schools.

First, as the centre of awareness for parents. As the centre of awareness of parents. This is because the low of parents' education make them do not know the importance of education of children from an early age. Parents in the central mountainous region of Papua, in general, more took his son to go into the garden in the woods from the giving opportunity to these children to attend school. It is the parents do because generally all family members working in the garden, and also in order for children to begin to recognise the natural life from an early age. This condition is also as stated in Modouw [14] that the public-gatherers in Papua generally live from the garden, and in these conditions, the children are invited to live in the garden of the school education which should be obtained by the children. More Grant [4] also suggests that the urgent role of all parties in society to pay attention to parents who had paid little attention to the education of children from an early age. Against this condition, the role of the church is very important for people in the central highlands of Papua utmost respect and trust in religious leaders. The church is not only present as a herald of religious teachings but also as a home for the family with the low level of education to gain an understanding of the importance of well-being that can be achieved through education. It is also as stated by Arifin [11] [15] also Nugroho [13] that early childhood education in remote areas still rely on the role of religious leaders are seen as driving awareness education for the family.

Second, as government partners to provide skills training to teach the teachers. Church in the central highlands of Papua and grow with solidarity by the congregation. The Church is also working with community leaders from various tribes and of interfaith is there to jointly give attention to early childhood education is an education that has not been getting a touch up by the government. It also points out Modouw [14] that the attention of the public at large in remote areas is still to basic education, while the early childhood education still ruled out because the parents believe that education for children beginning from elementary school. Based on these conditions, the church seeks to optimise its human resources are appropriate and are called to provide services in early childhood education, giving their time and energy voluntarily to serve as teachers 
for early childhood education every day for one hour at schools built by the people of the church. Moreover, the priests and religious leaders who have better education, providing training in how to teach children early age in schools built by the church, which is in the form of a science-based contextual teaching Papua and based on the values of love to children. The training was conducted by the church is well known and involves the local education office as a complementary partnership in the context of growth and development of early childhood education in the central highlands of Papua. It is also as stated by Sagala [16] that the community involvement of all layers of strata in giving attention to education will further strengthen togetherness attention to give a better future to the generations of a nation.

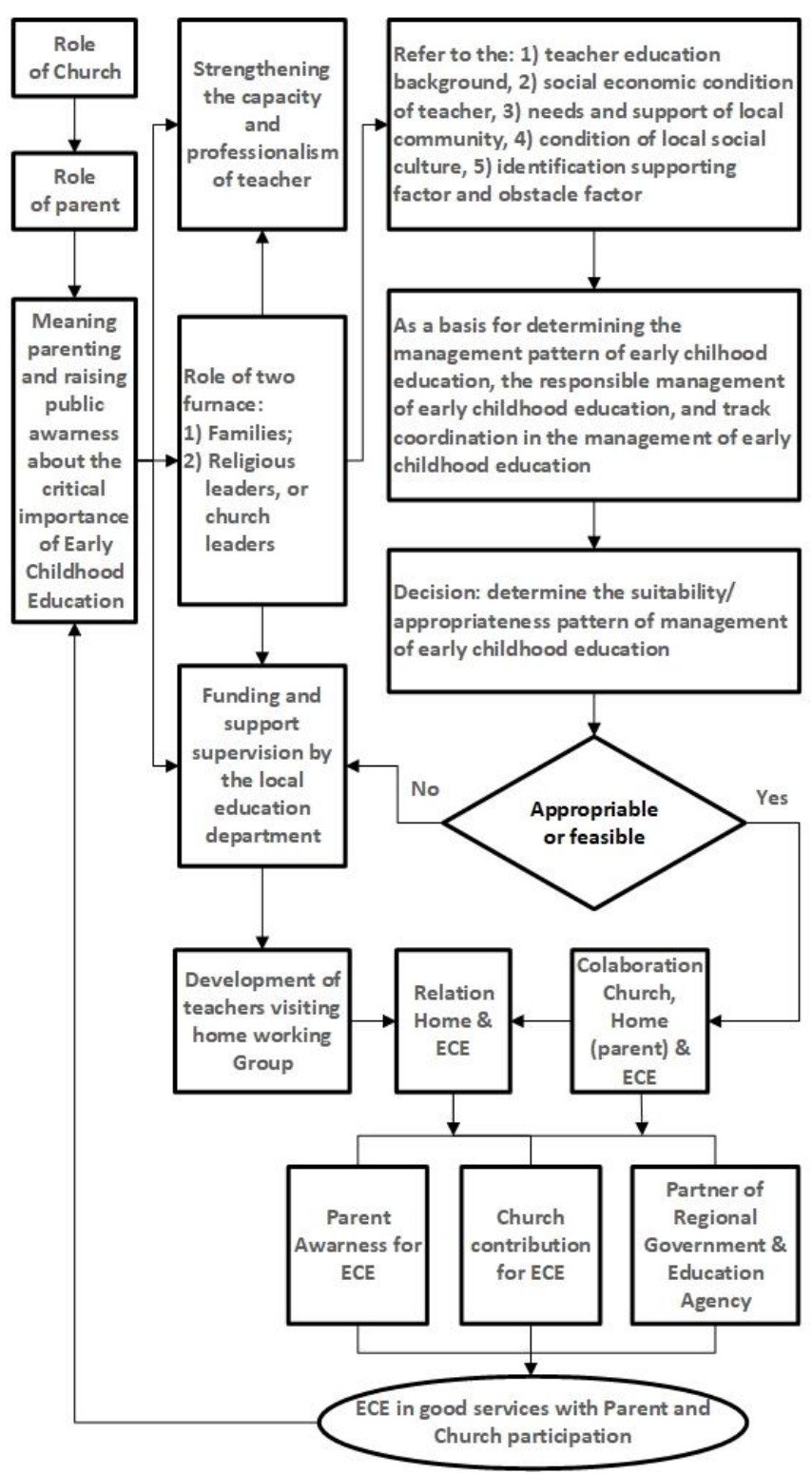

Fig. 1. Role's Church \& Parent in ECE in the Central Highlands of Papua

Third, as a partner of the government in providing learning facilities in schools. Local government and education authorities in the central highlands of Papua realise that the management of early childhood education could not rely on the role of education authorities alone but need to partner with a church or religious figure exist, this was because the mountains of central Papua respect religious leaders such and believes that the church can be a strategic partner of the government in providing socialization programs for early childhood education. As well as the financial constraints that exist in the education, churches can also contribute to the provision of learning and relevant to the learning process in schools of early childhood education which it is responsible.

The condition also as stated by Sonhadji [19] that the partnership between government and religious leaders, community leaders and traditional leaders will be easier for the government disseminate existing educational programs contextual approach that is easily accepted and understood by the local community. Purchase of a means of learning in early childhood education, which is managed by the church in the central highlands of Papua one of them comes from the donations of the people of the church every activity of the church as well as from businesses gardens managed by the church as well. From these two sources, the church leaders optimize existing funds for school management needs of early childhood education, which it is responsible. Donations from the community to the church is one of the church's success also in disseminating the importance of early childhood education as well as success in the form of awareness among the public in general about the meaning of education. This condition also as suggested by Brown and Duguid [17] and Moolenaar, et al [18] that the public awareness by leaders in the area of a school will open positive thinking parents the importance of education and opening them to be able to contribute to the progress of education in the school.

\section{CONCLUSION}

Parents believe that school-age children are about starting primary school. Besides parents also assume that the child must wait at school in the early childhood education will reduce their time working in the garden. Parents also assume that childhood education teachers more people from other ethnic communities, then the use of Indonesian would be difficult for children to understand because at home parents use the language of the local tribe. The existence of broad and good insights understood by parents in education for early childhood influences the increasing awareness of the community to give attention to children in terms of education, and also as learning for the community on the importance of education in the family. the role of parents towards children in Papua includes: (1) active and participatory in the organization or group of parents in each ECE; (2) participatory in consultation with children in ECE institutions; (3) active and involved in ECE activities; (4) active and involved in planning and organizing ECE activities; and (5) accepting teachers visiting home to build good relations between parents and teachers.

General community in Papua is abiding society on religion and respect for church leaders. Their role not only in church services but also sensitize the public about the importance of education and parenting. The church leaders with existing conditions provide the time and human 
resources that exist, active in establishing schools within the church, and the teachers who only have come from the young people who have concerns to help children early age. One of which is the role of the church which is not only as a journalist of religious teachings but also plays a role in making parents aware of the meaning of children's education as well as being strategic partners of Regional Government and Education Agency in order to provide understanding to the public about the importance of education for early childhood. The involvement of the church in the effort to develop Early Childhood Education programs is very effective because the church is still seen by the Central Mountains of Papua as a place to get life enlightenment and the significance of education as an effort to get out of poverty.

\section{REFERENCES}

[1] Jayawijaya Statistic Agency, Jayawijaya dalam Angka, Jayawijaya: Central Bureau of Statistics, 2014.

[2] C.E. Farhadian, Christianity, Islam and Nationalism in Indonesia, New York: Taylor and Francis, 2005, p. 103, 104.

[3] World Vision Indonesia, Annual Report of World Vision Indonesia Regio Papua, Jayapura Papua: World Vision Indonesia, 2014.

[4] C.A. Grant, Community Participation in Education, Massachusetts: Allyn and Bacon, Inc, 1979.

[5] S. Higgins, E. Hall, K. Wall, P. Woolner, \& C. McCaughey, The Impact of School Environments: A Literature Review, London: The Centre for Learning and Teaching. School of Education, Communication, and Language Science, University of Newcastle, 2005.

[6] Ministry of Education and Culture (MoEC), Republic of Indonesia. 2016. Profile: Directorate of Literacy and Equivalency Education Development. Jakarta: Directorate General of Early Childhood and Community Education. Directorate of Literacy and Equivalency Education Development.
[7] M.S. Knowles, E.F. Holton, \& R.A. Swanson, The Adult Learner, The Definitive Classic in Adult Education and Human Resource Development, Sixth Edition, Amsterdam: Elsevier Butterworth Heinceman, 2005.

[8] D.G. Myers, Social Psychology, $7^{\text {th }}$ edition, New York: McGraw Hill, 2002.

[9] I. Saleem \& A. Imam, Education and Social Sector: Issues and Challenges, Delhi: Regal Publications, 2012.

[10] A. Hermino, Education Leadership in the Globalization Era, Yogyakarta: Pustaka Pelajar, Inc, 2014.

[11] I. Arifin, The Bridging Programme for Early Childhood Education: Reggio Emilia Approach, Yogyakarta: Aditya Media, 2010.

[12] A. Elisabeth, Papua Roadmap, Jakarta: Lembaga Ilmu Pengetahuan Indonesia (LIPI), 2008.

[13] R.B.E.A. Nugroho, Usaha dan Sikap Gereja Papua, Jakarta: Majalah HIDUP edisi 17, terbit pada tanggal 28 April 2013, 2013.

[14] J. Modouw, Pendidikan dan Peradaban Papua, Yogyakarta: Bajawa Press, 2013

[15] I. Arifin, Kepemimpinan Kepala PAUD dalam Mengimplementasikan Pembelajaran Sentra: Studi Kasus PAUD Anak Saleh Malang, Yogyakarta: Aditya Media, 2009.

[16] S. Sagala (editor), Prof. Son Sang Pendidik Multikultural, Malang: Intelegensia Media, 2015.

[17] J. S. Brown, \& P. Duguid, The Social Life of Information, Boston: Harvard Business School Press, 2002.

[18] N. M. Moolenaar, A. J. Daly, \& P. J. C. Sleegers, Occupying the Principal Position: Examining Relationships Between Transformational Leadership, Social Network Position, and Schools' Innovative Climate, Educational Administration Quarterly, 2010, 46(5), 623-670.

[19] A. Sonhadji, Membangun Peradaban Bangsa dalam Perspektif Multikultural, Malang: Universitas Negeri Malang, Indonesia, 2015. 